\title{
PERSEPSI WANITA USIA SUBUR TERHADAP METODE KONTRASEPSI
}

\author{
Sumarni*
}

\begin{abstract}
ABSTRAK
Metode kontrasepsi adalah suatu cara yang ditempuh untuk menghindari atau mencegah terjadinya kehamilan.Masalah metode kontrasepsi merupakan hal yang sangat erat kaitannya dengan wanita subur.Tujuan dalam penelitian ini adalah untuk mengetahui persepsi wanita usia subur terhadap metode kontrasepsi di rumah bersalin Rajawali Kota Cirebontahun 2011. Jenis penelitian ini adalah deskriptif survey.Populasinya adalah wanita usia subur yang mengikuti program keluarga berencana di Rumah Bersalin Rajawali Kota Cirebon yaitu sebanyak 520 wanita usia subur. Jumlah sampel sebanyak 84 diambil dengan teknik accidental sampling.Pengambilan data dengan menggunakan kuesioner dan teknik analisa data menggunakan analisa univariate.Hasil penelitian secara keseluruhan menunjukan bahwa 51 responden (60,7\%) berpersepsi positif terhadap metode kontrasepsi, sedangkan yang berpersepsi negatif yaitu 33 responden $(39,3 \%)$. Berdasarkan hasil penelitian masih terdapat wanita usia subur yang belum memahami metode kontrasepsi efektif terpilih dan metode kontrasepsi mantap.
\end{abstract}

Kata kunci : Metode kontrasepsi, persepsi dan wanita usia subur

\begin{abstract}
Contraception method is a certain method that is used for avoiding or preventing pregnancy. This problem has strong correlation against fertile women.The purpose of this research is to know the perception of fertile women towards contraception method on Rajawali Maternity Hospital of Cirebon city, year 2011.Kind of method used on this research was descriptive survey.The objects of population were fertile women, who followed "Keluarga Berencana" program on Rajawali Maternity Hospital of Cirebon city, as many as 520 fertile women, 84 women taken as samples by accidental sampling method.Data collection was taken by questioners while data analysis by univariate analysis. The overall result showed, that 51 respondents $(60,7 \%)$ had positive perception towards contraception method, while the rest, 33 respondents $(39,3 \%)$, had negative perception.Based on that, there were fertile women, who still didn't understand the chosen effective contraception method and the good contraception method.
\end{abstract}

Key words: contraception method, perception and fertile women 


\section{PENDAHULUAN}

Bangsa Indonesia masih menghadapi berbagai persolaan kependudukan yang pelik. Yang dimana pendapat dari Irwan dan Suparmoko mengemukakan bahwa :"kenaikan penduduk yang sangat besar atau pesat ini sebabkan menurunnya tingkat kematian dan semakin tingginya tingkat kelahiran, sehingga bisa dilihat bahwa terdapat ketidakseimbangan dalam pertumbuhan penduduk. Ketidak seimbangan tersebut mengakibatkan menurunnya kualitas hidup yang memadai, tingkat kesejahtraan tidak merata. Salah satu cara untuk menekan laju pertumbuhan penduduk, alternatif yang diambil pemerintah adalah melalui kebijakan tentang program keluarga berencana (KB) merupakan usaha langsung keikutsertaan masyarakat untuk mengurangi tingkat kelahiran, melalui penggunaan alat kontrasepsi dengan berbagai metode kontrasepsi yang dapat dipilih seperti : Pil, suntik, implant, IUD, kondom secara efektif dan terdapat kontrasepsi mantap atau permanen seperti: MOW dan MOP. ${ }^{1}$

Berdasarkan laporan program keluarga berencana Kota Cirebon pada bulan Januari-Mei 2011, dengan jumlah pasangan usia subur sebanyak 44.458 pasangan, 34.388 pasangan merupakan peserta keluarga berencana $(\mathrm{KB})$ sedangkan 10.070 pasangan tidak mengikuti program keluarga berencana $(\mathrm{KB})$.Berdasarkan studi pendahuluan yang dilakukan penulis dengan cara wawancara terhadap 20 reponden wanita usia subur di rumah bersalin rajawali Kota Cirebon terhadap metode kontrasepsi, didapatkan 7 orang beranggapan bahwa menggunakan kontrasepsi pil jika ada yang terlupakan ibu akan langsung hamil, bahkan 5 orang beranggapan jika menggunakan kontrasepsi IUD/spiral dapat mengganggu hubungan seksual, 2 orang beranggapan tentang kontrasepsi MOW/steril bagi wanita mempunyai rasa takut tidak dapat memuaskan pasangannya, akan tetapi ada 6 orang beranggapan wajar semua alat kontrasepsi mempunyai efeksamping.

Berdasarkan uraian di atas, maka peneliti tertarik untuk melakukan pelitian untuk mengetahui Bagaimana Persepsi Wanita Usia Subur Terhadap Metode Kontrasepsi Di Rumah Bersalin Rajawali Kota Cirebon.

\section{METODE PENELITIAN}

Jenis penelitian ini adalah deskriptif survey, populasinya adalah wanita usia subur yang mengikuti program keluarga berencana di Rumah Bersalin Rajawali Kota Cirebon sebanyak 520 wanita usia subur yang diambil sebanyak 84 sebagai sample dengan teknik sample accidental sampling. ${ }^{2}$ Pengambilan data dengan menggunakan kuesioner dan teknik analisa data menggunakan analisa univariat.

\section{HASIL}

\section{Persepsi Wanita Usia Subur Terhadap Metode Kontrasepsi}

Hasil penelitian menunujukkan bahwa dari 84 Responden, yang mempunyai persepsi positif terhadap metode kontrasepsi sebanyak 51 respoden $(60,7 \%)$ dan mempunyai persepsi negatif sebanyak 33 responden $(39,3 \%)$.

\section{Persepsi Wanita Usia Subur Terhadap Metode Kontrasepsi Pil}

Hasil Penelitian menunjukkan bahwa dari 84 responden, yang mempunyai persepsi negatif terhadap metode kontrasepsi pil sebanyak 47 respoden (56\%) dan mempunyai persepsi positif sebanyak 37 responden (44\%). 


\section{Persepsi Wanita Usia Subur Terhadap Metode Kontrasepsi Suntik 1 Bulan}

Table 1. Persepsi Wanita Usia Subur Terhadap Metode Kontrasepsi Suntik 1 bulan

\begin{tabular}{lll}
\hline Persepsi & Frekuensi & $\%$ \\
\hline Negatif & 39 & 46,4 \\
Positif & 45 & 53,6 \\
\hline Jumlah & 84 & 100 \\
\hline
\end{tabular}

Berdasarkan tabel diatas bahwa wanita usia subur mempunyai persepsi positif terhadap metode kontrasepsi suntik 1 bulan sebanyak 45 respoden $(53,6 \%)$.

\section{Persepsi Wanita Usia Subur Terhadap Metode Kontrasepsi Suntik 3 Bulan}

Table 2. Persepsi Wanita Usia Subur Terhadap Metode Kontrasepsi Suntik 3 Bulan

\begin{tabular}{lll}
\hline Persepsi & Frekuensi & $\%$ \\
\hline Negatif & 33 & 39,3 \\
Positif & 51 & 60,7 \\
\hline Jumlah & 84 & 100 \\
\hline
\end{tabular}

Berdasarkan tabel diatas bahwa wanita usia subur mempunyai persepsi positif terhadap metode kontrasepsi suntik 3 bulan sebanyak 47 respoden (56\%).

\section{Persepsi Wanita Usia Subur Terhadap Metode Kontrasepsi Implant}

Table 3. Persepsi Wanita Usia Subur Terhadap Metode Kontrasepsi Implant

\begin{tabular}{lll}
\hline Persepsi & Frekuensi & $\%$ \\
\hline Negatif & 49 & 58,3 \\
Positif & 35 & 41,7 \\
\hline Jumlah & 84 & 100 \\
\hline
\end{tabular}

Berdasarkan tabel diatas bahwa wanita usia subur mempunyai persepsi negatif terhadap metode kontrasepsi implant sebanyak 49 respoden $(58,3 \%)$.

\section{Persepsi Wanita Usia Subur Terhadap Metode Kontrasepsi IUD}

Table 4. Persepsi Wanita Usia Subur Terhadap Metode Kontrasepsi IUD

\begin{tabular}{lll}
\hline Persepsi & Frekuensi & $\%$ \\
\hline Negatif & 58 & 69 \\
Positif & 26 & 31 \\
\hline Jumlah & 84 & 100 \\
\hline
\end{tabular}

Berdasarkan tabel diatas bahwa wanita usia subur mempunyai persepsi negatif terhadap metode kontrasepsi IUD sebanyak 58 respoden (69\%). 


\section{Persepsi Wanita Usia Subur Terhadap Metode Kontrasepsi MOW}

Table 5. Persepsi Wanita Usia Subur Terhadap Metode Kontrasepsi MOW

\begin{tabular}{lll}
\hline Persepsi & Frekuensi & $\%$ \\
\hline Negatif & 44 & 52,4 \\
Positif & 40 & 47,6 \\
\hline Jumlah & 84 & 100 \\
\hline
\end{tabular}

Berdasarkan tabel diatas bahwa wanita usia subur mempunyai persepsi negatif terhadap metode kontrasepsi MOW sebanyak 44 respoden $(52,4 \%)$.

\section{Persepsi Wanita Usia Subur Terhadap Metode Kontrasepsi MOP}

Table 6. Persepsi Wanita Usia Subur Terhadap Metode Kontrasepsi MOP

\begin{tabular}{lll}
\hline Persepsi & Frekuensi & $\%$ \\
\hline Negatif & 54 & 64,3 \\
Positif & 30 & 35,7 \\
\hline Jumlah & 84 & 100 \\
\hline
\end{tabular}

Berdasarkan tabel diatas bahwa wanita usia subur mempunyai persepsi negatif terhadap metode kontrasepsi MOP sebanyak 54 respoden $(64,3 \%)$.

\section{PEMBAHASAN}

\section{Persepsi Wanita Usia Subur Terhadap Metode Kontrasepsi}

Berdasarkan hasil penelitian yang dilakukan peneliti bahwa wanita usia subur mempunyai persepsi positif sebanyak 51 respoden $(60,7 \%)$ hal ini disebabkan karena wanita usia subur mengerti akan maanfaat dari penggunaan metode kontrasepsi. Yang dimana pendapat dari Walgito bahwa persepsi merupakan proses pengenalan atau identifikasi sesuatu dengan menggunakan panca indra. Kesan yang diterima individu sangat bergantung pada seluruh pengalaman yang telah diperoleh melalui proses berfikir dan belajar serta dipengaruhi oleh factor lain yang berasal dari dalam individu. ${ }^{3}$

\section{Persepsi Wanita Usia Subur Terhadap Metode Kontrasepsi Pil}

Berdasarkan hasil penelitian yang dilakukan peneliti bahwa Sebagian besar wanita usia subur mempunyai persepsi negatif sebanyak 47 respoden $(56 \%)$ hal ini disebabkan karena wanita usia subur kurang memahami dan kurang yakin akan keuntungan pemakaian kontrasepsi pil berdasarkan informasi dan pengalaman yang diterima sehingga persepsi, pandangan dan keyakinan dalam individu bersifat negatif. ${ }^{4}$

\section{Persepsi Wanita Usia Subur Terhadap Metode Kontrasepsi Suntik 1 Bulan}

Berdasarkan hasil penelitian yang dilakukan peneliti bahwa Sebagian besar wanita usia subur mempunyai persepsi positif sebanyak 45respoden $(53,6 \%)$ hal ini disebabkan karena wanita usia subur sesuai dengan pengalaman yang terjadi pada dalam diri individu merupakan salah satu faktor psikologis yang dapat mempengaruhi akseptor sehingga seseorang dapat menyimpulkan informasi dan menafsirkan pesan yang dipengaruhi oleh pengalamanpengalaman yang ada dalam diri individu. ${ }^{5}$ 


\section{Persepsi Wanita Usia Subur Terhadap Metode Kontrasepsi Suntik 3 Bulan}

Berdasarkan hasil penelitian yang dilakukan peneliti bahwa Sebagian besar wanita usia subur mempunyai persepsi positif sebanyak 51respoden $(60,7 \%)$ hal ini disebabkan karena wanita usia subur beranggapan pemakaian motede kontrasepsi ini lebih praktis, sedehana dan tidak perlu takut lupa, kontrasepsi suntik memiliki efektifitas tinggi bila penyuntikannya dilakukan secara teratur dan sesuai dengan jadwal yang telah ditentukan. Yang mempengaruhi persepsi diantaranya umur dengan bertambahnya umur seseorang akan terjadi perubahan pada aspek fisik dan psikologi, dimana pada aspek ini taraf berfikir seseorang semakin matang dan dewasa. ${ }^{5}$

\section{Persepsi Wanita Usia Subur Terhadap Metode Kontrasepsi Implant}

Berdasarkan hasil penelitian yang dilakukan peneliti bahwa Sebagian besar wanita usia subur mempunyai persepsi negatif sebanyak 49respoden $(58,3 \%)$ hal ini disebabkan karena wanita usia subur segan untuk menggunakannya karena kurang mengenalnya dan ketakutan karena membutuhkan pembedahan, tetapi masih banyak masyarakat yang tidak mengetahui metode kontrasepsi efektif terpilih lebih dikarenakan ketidaktahuan masyarakat tentang persyaratan dan keamanan metode kontrasepsi tersebut. ${ }^{6}$

\section{Persepsi Wanita Usia Subur Terhadap Metode Kontrasepsi IUD}

Berdasarkan hasil penelitian yang dilakukan peneliti bahwa Sebagian besar wanita usia subur mempunyai persepsi negatif sebanyak 58 respoden $(69 \%)$ hal ini disebabkan karena wanita usia subur beranggapan karena dapat mempengaruhi hubungan seksual. Pada saat ini kegiatan keluarga berencana masih kurang dalam metode kontrasepsi jangka panjang (MKJP), pada umumnya masyarakat lebih memilih metode non MKJP sehingga kontrasepsi jangka panjang kurang diminati. ${ }^{5}$

\section{Persepsi Wanita Usia Subur Terhadap Metode Kontrasepsi MOW}

Berdasarkan hasil penelitian yang dilakukan peneliti bahwa Sebagian besar wanita usia subur mempunyai persepsi negatif sebanyak 44 respoden $(52,4 \%)$ hal ini disebabkan karena wanita usia subur sedikit sekali mengetahui tentang kontrasepsi MOW. Karena kurangnya informasi yang tepat dan masih banyak masyarakat yang belum mengetahui metode kontrasepsi mantap lebih dikarenakan oleh ketidaktahuan masyarakat tentang persyaratan dan keamanan metode kontrasepsi tersebut. Alat kontrasepsi mantap khususnya MOW dipengaruhi beberapa faktor antara lain tingkat ekonomi, usia dan paritas. ${ }^{5}$

\section{Persepsi Wanita Usia Subur Terhadap Metode Kontrasepsi MOP}

Berdasarkan hasil penelitian yang dilakukan peneliti bahwa Sebagian besar wanita usia subur mempunyai persepsi negatif sebanyak 54 respoden $(64,3 \%)$ hal ini disebabkan karena wanita usia subur tidak mengetahui terhadap kontrasepsi MOP, hal ini menyangkut kontrasepsi pria jenis vasektomi jumlah permintaanya tidak begitu signifikan dibandingkan alat kontrasepsi lainnya. Hal ini disebabkan karena salah persepsi dari kalangan masyarakat bahwa jika menggunakan alkon vasektomi dapat menyebabkan tidak terjadinya ereksi. ${ }^{5}$

\section{SIMPULAN}

1. Sebagian besar persepsi wanita usia subur terhadap metode kontrasepsi di Rumah Bersalin Rajawali Kota Cirebon sebanyak 51 responden $(60,7 \%)$. 
2. Sebagian besar persepsi wanita usia subur terhadap metode kontrasepsi dalam bentuk kontrasepsi pil berpersepsi negatif sebanyak 47 responden $(56 \%)$.

3. Sebagian besar persepsi wanita usia subur terhadap metode kontrasepsi dalam bentuk kontrasepsi suntik 1 bulan berpersepsi positif sebanyak 45 responden $(53,6 \%)$,

4. Sebagian besar persepsi wanita usia subur terhadap metode kontrasepsi dalam bentuk kontrasepsi suntik 3 bulan berpersepsi positif sebanyak 51 responden $(60,7 \%)$.

5. Sebagian besar persepsi wanita usia subur terhadap metode kontrasepsi dalam bentuk kontrasepsi implant berpersepsi negatif sebanyak 49 responden $(58,3 \%)$.

6. Sebagian besar persepsi wanita usia subur terhadap metode kontrasepsi dalam bentuk kontrasepsi IUD berpersepsi negatif sebanyak 58responden (69\%).

7. Sebagian besar persepsi wanita usia subur terhadap metode kontrasepsi dalam bentuk kontrasepsi MOW berpersepsi negatif sebanyak 44 responden $(52,4 \%)$.

8. Sebagian besar persepsi wanita usia subur terhadap metode kontrasepsi dalam bentuk kontrasepsi MOP berpersepsi negatif sebanyak 54 responden $(64,3 \%)$.

\section{SARAN}

1. Bagi Wanita Usia Subur

Agar persepsi wanita usia subur lebih baik lagi terhadap metode kontrasepsi diperlukan upaya promotif terhadap pasangan usia subur dengan memberikan penyuluhan secara optimal oleh petugas kesehatan yang terkait agar wanita usia subur mengetahui dan mengerti terhadap metode kontrasepsi

2. Bagi Institusi Penyelenggara Pelayanan Kesehatan

Agar lebih ditingkatkan lagi pelaksanaan penyuluhan atau akses informasi mengenai alat kontrasepsi baik di Rumah Sakit, Puskesmas, Klinik Kesehatan, Rumah Bersalin dan BPS yang menjadi ujung tombak pelayanan kesehatan

3. Bagi Bidan

Selalu menjadi motivator bagi ibu-ibu untuk meningkatkan pengetahuan mengenal alatalat kontrasepsi dan lebih banyak lagi memberikan KIE mengenai alat kontrasepsi tidak hanya memberikan pelayanan saja, selain itu bidan lebih ditingkatkan lagi kerjasama lintas program dalam menyediakan alat kontrasepsi

4. Bagi Peneliti Lain

Dengan melihat rincian hasil penelitian diharapkan dapat dikembangkan lagi penelitian yang terkait dengan pengetahuan yang lebih spesifik terhadap metode kontrasepsi.

\section{DAFTAR PUSTAKA}

1. Anonim. Tentang Akseptor Keluarga Berencana. (Dinkes) [diakses Tanggal 21 Maret 2011].diunduh dari http//:www.demografi-indonesia.com

2. Arikunto, S. Prosedur Penelitian Suatu Pendekatan Praktek. Jakarta :Rineka Cipta;2006.

3. Walgito, Bimo. Pengantar Psikologi Umum. Edisi Revisi Ketiga. Yogyakarta:CV Andi Offset;2002

4. Sobur, Alex. Psikologi Umum Dalam Lintasan Sejarah. Bandung :CV Pustaka Setia;2003.

5. Wiyana, D. Persepsi Terhadap Metode Kontrasepsi. (diakses Tanggal 7 Juni 2011). Diunduh dari http//:=www.mediacoastore.com

6. BKKBN. Alat Kontrasepsi Bawah Kulit (Implant/Susuk KB).[diakses tanggal 10 juni 2011]. Diunduh dari http//:www.bidblogspot.Com. 